\title{
Organophilic clays and their application in atrazine adsorption
}

\author{
E. A. Silva Filho'*, F. S. D’Agostini Vazzoler ${ }^{1}$, H. Vazzoler ${ }^{2}$, F. Uliana ${ }^{1}$, F. R. Valenzuela Diaz ${ }^{2}$ \\ ${ }^{1}$ Universidade Federal do Espírito Santo, Departamento de Química, Laboratório de Físico-Química, \\ Vitória, ES, Brazil \\ ${ }^{2}$ Universidade de São Paulo, Departamento de Engenharia Metalúrgica e de Materiais, \\ Laboratório de Sólidos Não metálicos, São Paulo, SP, Brazil
}

\begin{abstract}
Atrazine's adsorptive capabilities make the use of clays practical and effective. Three types of organophilic clays modified by cationic surfactants with the ability of one of these clays to adsorb atrazine in an aqueous medium are discussed in this work. The modification in clays was done with the surfactants cetyltrimethylammonium bromide, cetyltrimethylammonium chloride, and dodecyltrimethylammonium chloride. The X-ray diffraction data indicated different lamellar expansions for the three organophilic clays obtained when compared to in natura clay, proving the presence of quaternary ammonium salts in the interlamellar space. There was also a decrease in the specific surface area showing less accessibility to the lamellar spaces due to the presence of surfactants. The thermogravimetric analysis showed a negative variation profile in all the clays. The adsorption test showed a better capacity for atrazine adsorption in the organophilic clay of $64 \%$ when compared with $36 \%$ of in natura clay, and it followed the Freundlich isotherm model.
\end{abstract}

Keywords: adsorption, atrazine, organophilic clays, surfactants, wastewater.

\section{INTRODUCTION}

Clays are very versatile and abundant materials and used as raw material for various applications, such as building materials, ceramics, paper, petroleum drilling, pharmaceutical industry, as well as adsorbents, catalysts or catalyst carriers, ion exchangers, and others, depending on the specific property that it presents $[1,2]$. Many materials developed in the most diverse fields of science become applicable through the improvement of technologies and the acquisition of new materials. From this point of view, clay materials present a great promise in the optimization of new materials due mainly to their low cost and availability. Some studies have shown the application of adsorption systems to phenolic compounds in which alginate inserted nanocomposites using calcium chloride solution for the removal of phenolic compounds in aqueous systems were developed [3]. In this study, it was shown that the organophilic clay modified with the cationic surfactant hexadecyltrimethylammonium bromide resulted in a good organophilization efficiency. In addition, adsorption results were obtained in agitation systems with different times, obtaining the maximum adsorption capacity of 0.334 and $0.118 \mathrm{mg} / \mathrm{g}$ for phenolic compounds 4-chlorophenol (4CF) and phenol, respectively. Another application for organophilic clays was studied by Iannuccelli et al. [4], with the aim of modifying and improving the biological activity

*eloisilv@gmail.com

Dhttps://orcid.org/0000-0002-9306-7882 of gentamicin (GM) on the evaluation of crude bentonite $\mathrm{Bt}$ ) for the development of new gentamicin, a clay hybrid material for topical use. For this, the bentonite was treated with sodium chloride and subsequently, dispersions of bentonite and gentamicin were prepared. Controlled $\mathrm{X}$-ray powder diffraction, thermogravimetry coupled to mass spectrometry, and molecular dynamics simulations indicated monolayer arrangement of gentamicin within the montmorillonite structure without producing substantial effects on the layer periodicity. Concerning skin biomedical application, unlike the pure antibiotic permeating along the transfollicular pathway across stratum corneum, the organomodified Bt/GM would favor the trans-epidermal route along inter-cluster corneocyte region, as in vivo skin penetration studies by means of tape stripping test indicated. The GM intercalation could represent a potential advantageous approach in the contribution to a new antibiotic material [4].

Pandey and Ramontja [5] presented a review on the application of modified bentonites as adsorbents in the remediation of wastewater, given the importance of these materials in the organic and inorganic removal of several pollutants, evaluating different parameters of physical processes such as the impact of $\mathrm{pH}$, the adsorption mechanism and the applicability of several kinetic and thermodynamic models of adsorption. It was verified that the great majority of the results showed that the adsorption for several pollutants followed a pseudo-second-order and the isotherms conformed to the Langmuir model. In addition, the great potential of bentonite in relation to other existing materials was highlighted, however with a disadvantage of the small pore size, suggesting that the diameters for the 
selective adsorption of pollutants should be improved. The authors concluded that the research should be focused in the coming years on bentonite and modified bentonites due to the high interest in water treatment in removing traces of organic, inorganic, and pathogenic contaminants [5].

Among its diverse applications, the use of clay as an adsorbent in the clarification of oils, treatment of wastewater, and retention of agrochemicals has stood out in recent years. In this sense, this work aimed to prepare and characterize organophilic clays and verify their application in the removal of atrazine in wastewater. Atrazine was chosen because there is still no efficient method for removing it from the wastewater. Atrazine is a low-cost herbicide, widely applied in the cultivation of corn, sugarcane, coffee, pineapple, banana, lettuce, and other fruits and vegetables. According to the plan for the years 2017-2020 of the Brazilian Health Regulatory Agency (ANVISA), atrazine is classified as toxicity class III, which means medium-toxic compounds. The maximum value for this compound in drinking water is $2 \mu \mathrm{g} / \mathrm{L}$ and the World Health Organization (WHO) sets the value of $100 \mu \mathrm{g} / \mathrm{L}$, corresponding to the sum of atrazine and its chloro-s-triazine metabolites $[6,7]$.

\section{MATERIALS AND METHODS}

Preparation of organophilic clays: a bentonite clay (Bentogel, Campina Grande-PB, Brazil) was prepared by organophilization by the addition of three different surfactants, cetyltrimethylammonium bromide (CTAB), cetyltrimethylammonium chloride (CTAC), and dodecyltrimethylammonium chloride (DTAC), all from Sigma-Aldrich (99\% pure). The method used for the organophilization was according to Valenzuela-Díaz [8, 9], using the ratio of $60 \mathrm{~g}$ of bentogel clay to $1500 \mathrm{~mL}$ of distilled and deionized water. For the sodification, $20 \% \mathrm{~m} / \mathrm{m} \mathrm{Na}_{2} \mathrm{CO}_{3}$ (Vetec) and $50 \% \mathrm{~m} / \mathrm{m}$ ammonium quaternary salt solution were used for the organophilization; in both steps, the surplus was worked around $150 \% \mathrm{~m} / \mathrm{m}$ of CTAC ( $80 \mathrm{meq} / 100 \mathrm{~g}$ of clay). After organophilization, the suspension was vacuum filtered, washing with plenty of deionized and distilled water. The retained product was oven dried at $60{ }^{\circ} \mathrm{C}$ for 48 $\mathrm{h}$, disintegrated in the mortar, sifted below 200 mesh, and identified as organophilic clays A1 (cetyltrimethylammonium bromide), A2 (cetyltrimethylammonium chloride), and A3 (dodecyltrimethylammonium chloride).

Determination of the ion exchange capacity (IEC) of clay: IEC was determined using the traditional Kjeldahl distillation method, also called the ammonia nitrogen method. For this procedure, $5 \mathrm{~g}$ of in natura clay was transferred to a $500 \mathrm{~mL}$ conical flask containing $200 \mathrm{~mL}$ of a $3 \mathrm{~mol} / \mathrm{L}$ ammonium acetate aqueous solution. This mixture was stirred for $12 \mathrm{~h}$ at $100 \mathrm{rpm}$, then centrifuged for $5 \mathrm{~min}$ at $1000 \mathrm{rpm}$. The supernatant was removed, and the remaining clay was washed with ethyl alcohol to remove the excess ammonium acetate and centrifuged again. The final solid was oven dried at $60^{\circ} \mathrm{C}$ for $24 \mathrm{~h}$. Then, $1.5 \mathrm{~g}$ of this solid was placed in a Kjeldahl flask together with $50 \mathrm{~mL}$ of deionized water, 3 drops of phenolphthalein, and $20 \% \mathrm{NaOH}$ solution until the medium turned slightly pink. The flask was coupled to a distillation system. With heating, the ammonia was released from the mixture and collected in a conical flask containing $50 \mathrm{~mL}$ of $4 \%$ boric acid, 3 drops of bromocresol red, and 3 drops of methyl red. The solution went from red to green. After distillation was completed, the green-colored solution was titrated with $0.1 \mathrm{~mL} / \mathrm{L} \mathrm{HCl}$, whose correction factor is $\mathrm{f}=1.05$ and the IEC was calculated by:

$$
\mathrm{IEC}=\frac{[\text { Concentration of acid }(\mathrm{mol} / \mathrm{L}) \cdot \mathrm{f} \cdot \text { Volume of acid }(\mathrm{mL})] \cdot 100}{\text { Mass of clay }(\mathrm{g})}
$$

$X$-ray diffraction $(X R D)$ : $\mathrm{XRD}$ data of in natura and organophilic clays were collected using a diffractometer (D8 Discover, Bruker) operating with CuK $\alpha$ radiation $(\lambda=1.54056$ $\AA$ ) at $50 \mathrm{kV}$ and $100 \mathrm{~mA}$. Powder XRD patterns were obtained in step scanning mode, $2 \theta=2-90^{\circ}$ with a step of $0.01^{\circ}$. Fourie transform infrared spectroscopy (FTIR): the analyses were performed using a spectrometer (Spectrum 400 FT-IR, Perkin Elmer) in the range of 400 to $4000 \mathrm{~cm}^{-1}$, in attenuated total reflectance (ATR) mode, using a $\mathrm{ZnSe}$ crystal with a resolution of $4 \mathrm{~cm}^{-1}$ and recording the average of 16 scans. Thermogravimetric analysis (TG): TG was performed using a thermal analyzer (SDT Q600, TA Instr.) in an oxidizing atmosphere with synthetic air with a heating rate of $20^{\circ} \mathrm{C} / \mathrm{min}$ and final temperature of $1000^{\circ} \mathrm{C}$.Brunauer-Emmett-Teller (BET) specific surface area analysis: BET analysis was performed with a gas sorption analyzer (Autosorb, Quantachrome) at 77 $\mathrm{K}$ and $\mathrm{N}_{2}$ flow as the adsorbate.

In natura and organophilic clay adsorption tests: the adsorption tests were performed with atrazine (SigmaAldrich, 99.1\%) using a shaker with thermostatized bath at constant ambient temperature $\left(25^{\circ} \mathrm{C}\right)$ for $24 \mathrm{~h}$ under stirring at $100 \mathrm{rpm}$. In this assay, the adsorption efficiency per unit mass of the adsorbents was determined by high-performance liquid chromatography (HPLC). The adsorbents to be evaluated were chosen based on the results of characterization of the organophilic clays obtained in this study, prevailing the one that had better efficiency in the organophilization, considering the analyses of XRD, TG, and surface area. Thus, the adsorption tests were carried out for an organophilic clay and for the clay in natura. The method used to carry out the adsorption tests and the preparation of the isotherms was the bottle-point method $[9,10]$. Previously, $0.5 \mathrm{~g}$ of each adsorbent (in natura and A1) and $200 \mathrm{~mL}$ of the atrazine solution in concentrations ranging from 200 to $900 \mu \mathrm{g} / \mathrm{L}$ with $\mathrm{pH} 6.5 \pm 0.5$ were added to Erlenmeyer flasks. Then, the flasks were placed on a shaking thermostatic bath at $25^{\circ} \mathrm{C}$ for $24 \mathrm{~h}$ and stirred at 100 $\mathrm{rpm}$. The samples were centrifuged for $15 \mathrm{~min}$ at $4000 \mathrm{rpm}$ and the supernatants were properly packaged and analyzed by HPLC. For the HPLC, it was used a column C18 ACE 5 C18 with internal diameter dimensions of $250 \times 4.6 \mathrm{~mm}$, a mobile phase of acetonitrile and water (1:1) operating in an isocratic elution mode $(1 \mathrm{~mL} / \mathrm{min})$, an injection volume of $20 \mu \mathrm{L}$ and a wavelength of $220 \mathrm{~nm}$. The adsorption tests were performed in duplicate. 


\section{RESULTS AND DISCUSSION}

The analysis of cation exchange capacity was important for modified clays, due to the significant exchange of sodium present between the lamellar structure of clays by surfactant ions. According to the volume of titrant acid $(\mathrm{V}=11.4 \mathrm{~mL})$ and applying Eq. A, IEC value of $79.8 \mathrm{meq} / 100 \mathrm{~g}$ of clay was obtained for the in natura clay. This result was consistent with the IEC data of smectite clay minerals found in the literature, which show for the Brazilian smectite clays IEC values ranging from 22 to $151 \mathrm{meq} / 100 \mathrm{~g}$ of clay $[9,10]$. The variation in the IEC of the same clay mineral is also related to the degree of impurity; the higher it is, the lower the IEC $[10,11]$. From the X-ray diffractograms presented in Fig. 1 , the in natura clay presented the basal plane reflection at $6.57^{\circ}$ and the organophilic clays A1, A2, and A3 presented this reflection peak at $4.17^{\circ}, 4.34^{\circ}$, and $4.08^{\circ}$, respectively. So, comparing the diffractograms of the organophilic clays with the in natura clay, it was observed that the $2 \theta$ angle of the peak corresponding to (001) basal reflection was displaced to lower values, indicating the presence of the organic molecules of quaternary ammonium surfactants in the interlamellar spaces of the clay, increasing the basal distance between the layers of clay minerals. In fact, the basal distance $\left(\mathrm{d}_{001}\right)$ was increased, being $13.4,21.1,20.4$, and $21.7 \AA$ to in natura, A1, A2, and A3 clays, respectively. The increase in the basal distance occurs according to the type of surfactant and its concentration, being possible to obtain different basal increases and, consequently, organophilic clays with different characteristics, allowing to adsorb molecules with different or specific dimensions $[8,12]$. For the organophilic clays studied, there were no significant differences between them, probably due to the similar structure of the surfactants used. According to Bertagnolli [10], the differences in the values of the interplanar distances are related to the positioning and type of density of the intercalated quaternary ammonium cation.

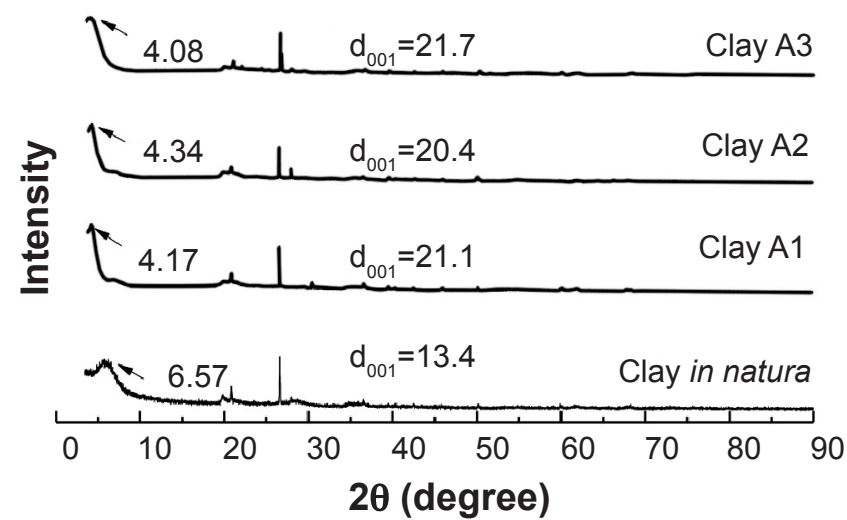

Figure 1: X-ray diffractograms of in natura and organophilic A1, $\mathrm{A} 2$, and A3 clays.

The results of the analysis by infrared spectroscopy for the in natura and the organophilic clays are shown in Fig. 2 and display characteristic bands of the smectite group in all spectra, indicating the permanence of the clay structure even after the modifications. The spectra of the organophilic clays presented additional bands, characteristic of the intercalated surfactants. The FTIR spectra (Fig. 2) of the in natura and the modified $\mathrm{A} 1, \mathrm{~A} 2$, and $\mathrm{A} 3$ clays presented the $\mathrm{OH}$ stretching as a broad band in the $3600-3660 \mathrm{~cm}^{-1}$ range, involving the contributions of the $\mathrm{OH}$ groups coordinated to different octahedral cations. The Si-O stretching band at $1003 \mathrm{~cm}^{-1}$ had the contributions of in-plane Si-O-Si stretching vibrations, and the band at 1113 $\mathrm{cm}^{-1}$ was assigned to perpendicular $\mathrm{Si}-\mathrm{O}$ vibration. A single band at $914 \mathrm{~cm}^{-1}$ in the spectra confirmed the dominance of Al-O within octahedral sites. As reported [8], and shown in Table I, the two bands at 2850 and $2930 \mathrm{~cm}^{-1}$ that appeared in the spectra of A1, A2 and A3 modified clays were assigned to the $\mathrm{CH}_{2}$ group and the band at $1480 \mathrm{~cm}^{-1}$ referred to the $\mathrm{CH}_{3}$ group from the quaternary ammonium surfactant molecules, evidencing the effective organophilization of the in natura clay.

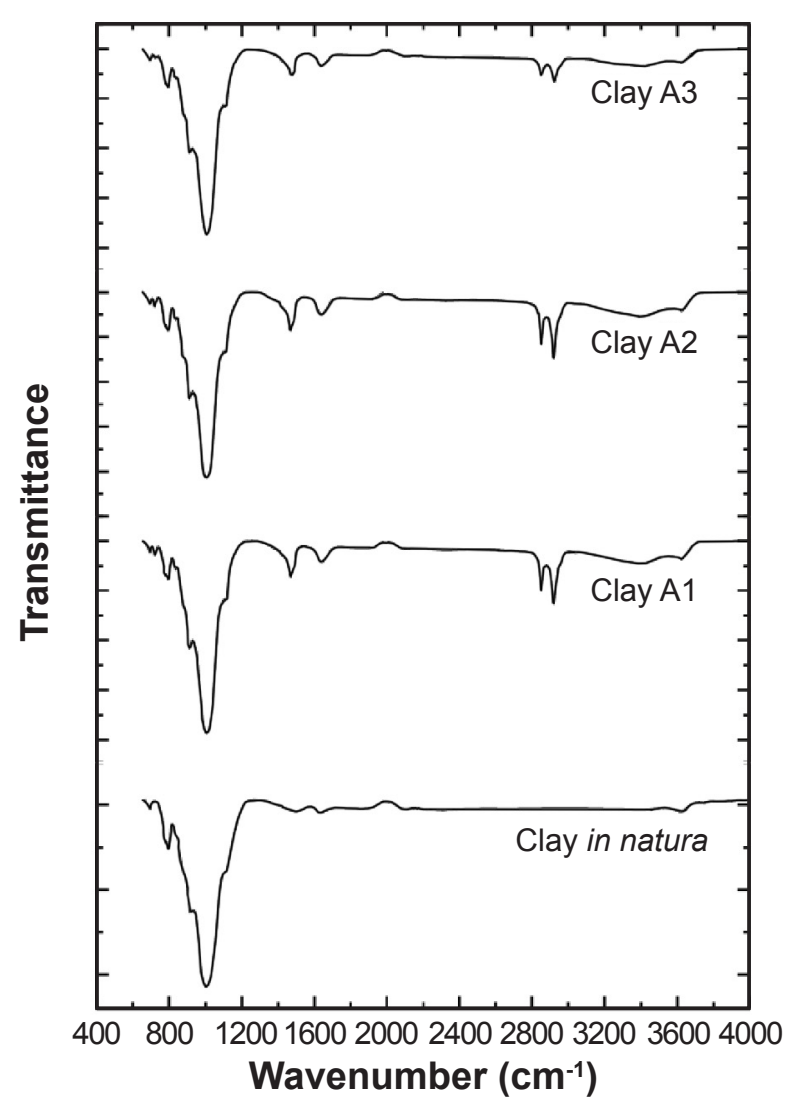

Figure 2: FTIR spectra of in natura and organophilic A1, A2, and A3 clays.

Table I - FTIR bands for in natura and organophilic A1, A2, and $\mathrm{A} 3$ clays.

\begin{tabular}{ccc}
\hline Binding & Band $\left(\mathrm{cm}^{-1}\right)$ & Clay \\
\hline $\mathrm{Si}-\mathrm{O}$ & 1007 & In natura, $\mathrm{A} 1, \mathrm{~A} 2, \mathrm{~A} 3$ \\
$\mathrm{~A} 1-\mathrm{O}$ & 915 & In natura, $\mathrm{A} 1, \mathrm{~A} 2, \mathrm{~A} 3$ \\
$\mathrm{O}-\mathrm{H}$ & 3700 & In natura, $\mathrm{A} 1, \mathrm{~A} 2, \mathrm{~A} 3$ \\
$\mathrm{CH}_{2}$ & 2920,2850 & $\mathrm{~A} 1, \mathrm{~A} 2, \mathrm{~A} 3$ \\
$\mathrm{CH}_{3}$ & 1470 & $\mathrm{~A} 1, \mathrm{~A} 2, \mathrm{~A} 3$ \\
\hline
\end{tabular}


From the TG curves shown in Fig. 3, all samples exhibited a mass loss between 25 and $150{ }^{\circ} \mathrm{C}$, attributed to the loss of water molecules adsorbed on the surface of the clays and the water molecules of hydration around the interchangeable cations in the interlamellar space. Subsequently, the samples $\mathrm{A} 1, \mathrm{~A} 2$, and $\mathrm{A} 3$ underwent a mass loss between 250 and $400{ }^{\circ} \mathrm{C}$, attributed to the decomposition of the organics from the quaternary ammonium salt [13-16]. Finally, the last decomposition step occurred due to the dehydroxylation of the clay structure characterized by slopes between 600 and $700{ }^{\circ} \mathrm{C}$ for the organophilic samples and between 400 and $600{ }^{\circ} \mathrm{C}$ for the in natura clay. The temperature range of the mass loss of the structural hydroxyls for the in natura clay agreed with the one found by Santos [14], which was 400 to $700{ }^{\circ} \mathrm{C}$.

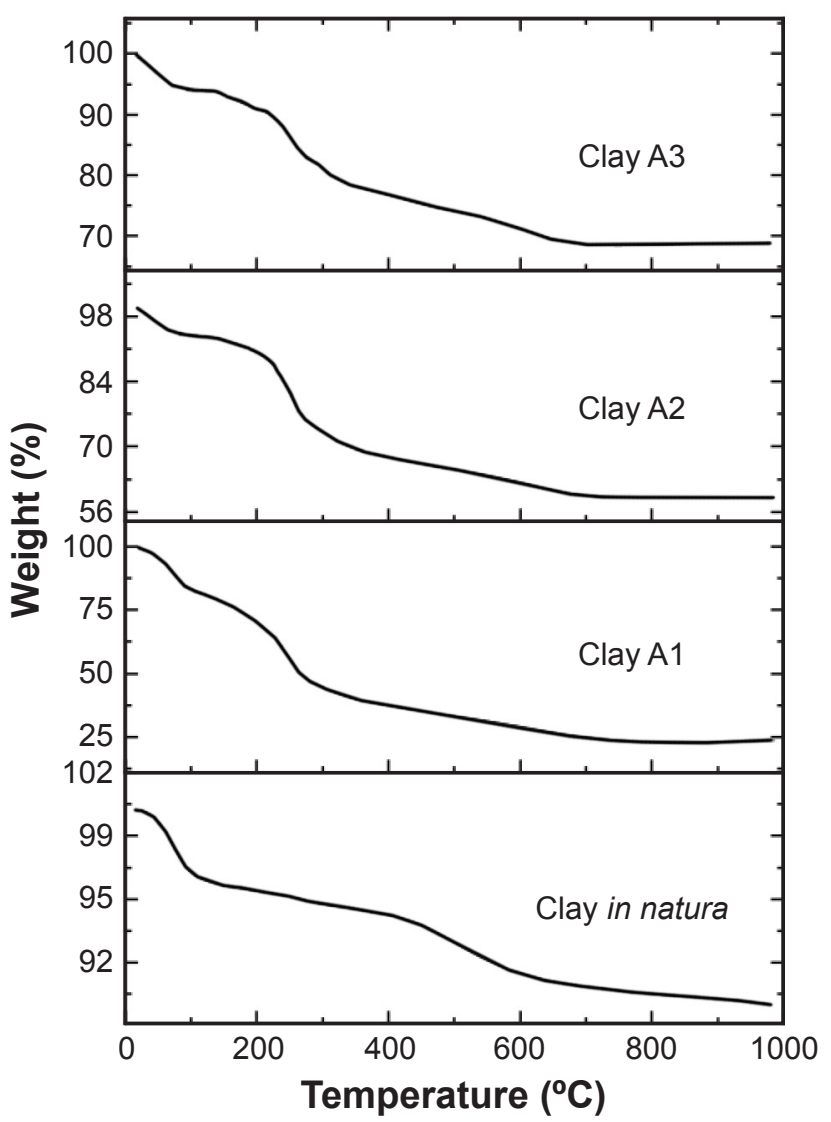

Figure 3: TG curves of in natura and organophilic A1, A2, and A3 clays.

Table II - BET surface area $\left(\mathrm{m}^{2} / \mathrm{g}\right)$ of in natura and organophilic clays.

\begin{tabular}{cccc}
\hline In natura & $\mathrm{A} 1$ & $\mathrm{~A} 2$ & $\mathrm{~A} 3$ \\
\hline 50.76 & 5.56 & 7.68 & 6.54 \\
\hline
\end{tabular}

The results of the surface area measurements are shown in Table II. For the organophilic clays, a decrease of the surface area in relation to the value of the in natura clay occurred due to the presence of the molecules of the quaternary ammonium salts between clay lamellae, characterizing a good organophilization. The cation salts can block this space by preventing the passage of $\mathrm{N}_{2}$ molecules and occupying clay active sites that could be available for $\mathrm{N}_{2}[8,10]$.

Adsorption results of atrazine by in natura and organophilic clays: the organophilic clay selected for the adsorption of atrazine was A1 and its adsorption capacity was compared with the in natura clay. The amount of atrazine adsorbed by the mass of the adsorbents is presented by the adsorption isotherms shown in Fig. 4a (in natura clay as adsorbent) and Fig. 4b (A1 clay as adsorbent). The adsorptive capacities (Qe), calculated by Eq. B [17-21] for each point, were obtained from the initial concentrations (Ci) and the residual concentrations of atrazine $(\mathrm{Ce})$, which were detected in HPLC. From Fig. 4, it is observed that A1 clay exhibited an adsorption capacity much higher than in natura clay. Subsequently, the isotherms in Fig. 4 were studied from the linearized equations for the Langmuir (Eq. C) and Freundlich (Eq. D) isotherm models [21, 22] of the clay adsorption assays. $\mathrm{K}_{\mathrm{L}}(\mathrm{L} / \mathrm{g})$ is the Langmuir constant, Qe is the amount of adsorbate per unit mass of adsorbent, $\mathrm{b}$ is the constant of proportionality and $\mathrm{K}_{\mathrm{F}}$ is the Freundlich constant. The linearized results for the atrazine adsorption by the in natura and A1 clays are displayed in Figs. 5a and $5 \mathrm{~b}$ for Langmuir equation, and in Figs. $5 \mathrm{c}$ and $5 \mathrm{~d}$ for the Freundlich equation.

$$
\begin{aligned}
& \mathrm{Qe}=\frac{(\mathrm{Ci}-\mathrm{Ce}) . \text { Volume of solution }}{\text { Mass of clay }} \\
& \frac{\mathrm{Ce}}{\mathrm{Qe}}=\frac{1}{\mathrm{~b} \cdot \mathrm{K}_{\mathrm{L}}}+\frac{1}{\mathrm{~K}_{\mathrm{L}}} \mathrm{Ce} \\
& \ln \mathrm{Qe}=\ln _{\mathrm{f}}+\frac{1}{\mathrm{n}} \operatorname{lnCe}
\end{aligned}
$$

Table III shows the adsorption parameters for the linear adjustment of these isotherms obtained for the in natura and organophilic A1 clays. The model that best fitted the experimental data was the Freundlich model, which suggested that the adsorption of atrazine occurred in multilayers by both in natura and A1 clays. According to the literature, the constant $1 / \mathrm{n}$ indicates how spontaneous and strong the adsorption is, that is, the existence of affinity between the adsorbate and the adsorbent. Thus, the lower $1 / \mathrm{n}$, the greater the adsorption force. In addition, their values must be between 0 and 1 , for the adsorption to be considered favorable [23-25]. The $1 / n$ value of A1 clay was the lowest, indicating that it adsorbed atrazine more strongly than in natura clay. The $\mathrm{K}_{\mathrm{F}}$ value (Table III) was greater for A1 clay, indicating that its atrazine adsorption capacity was higher than in natura clay. Therefore, the organophilic A1 clay proved to be an adsorbent with a performance far superior to the in natura clay, validating and confirming the importance of the organophilization process. Reported studies [25-27] show that the Freundlich isotherm is the function that best fits the data related to the adsorption of contaminants in water treatment processes, in line with the obtained in this study. 


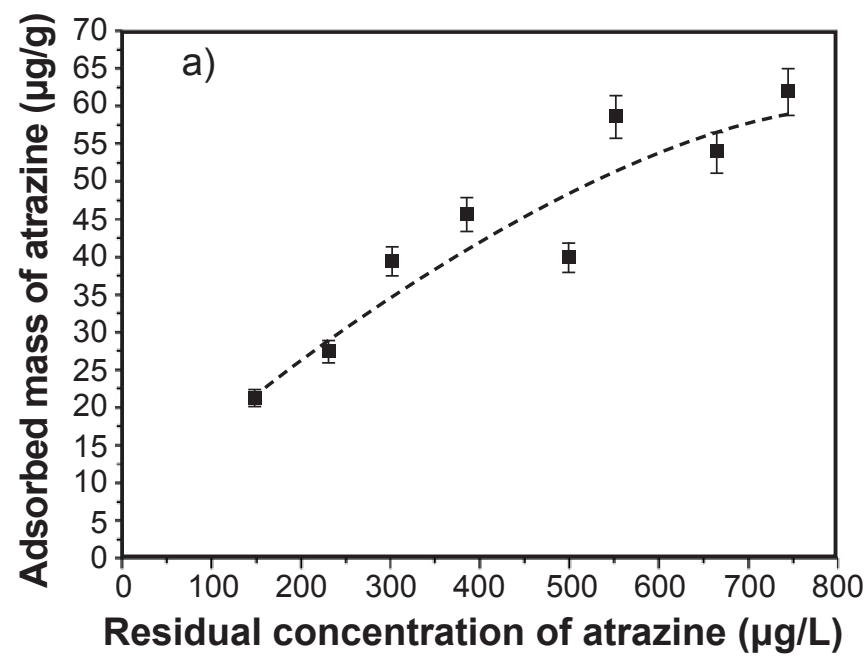

Figure 4: Adsorption isotherms of: a) in natura clay; and b) A1 clay.
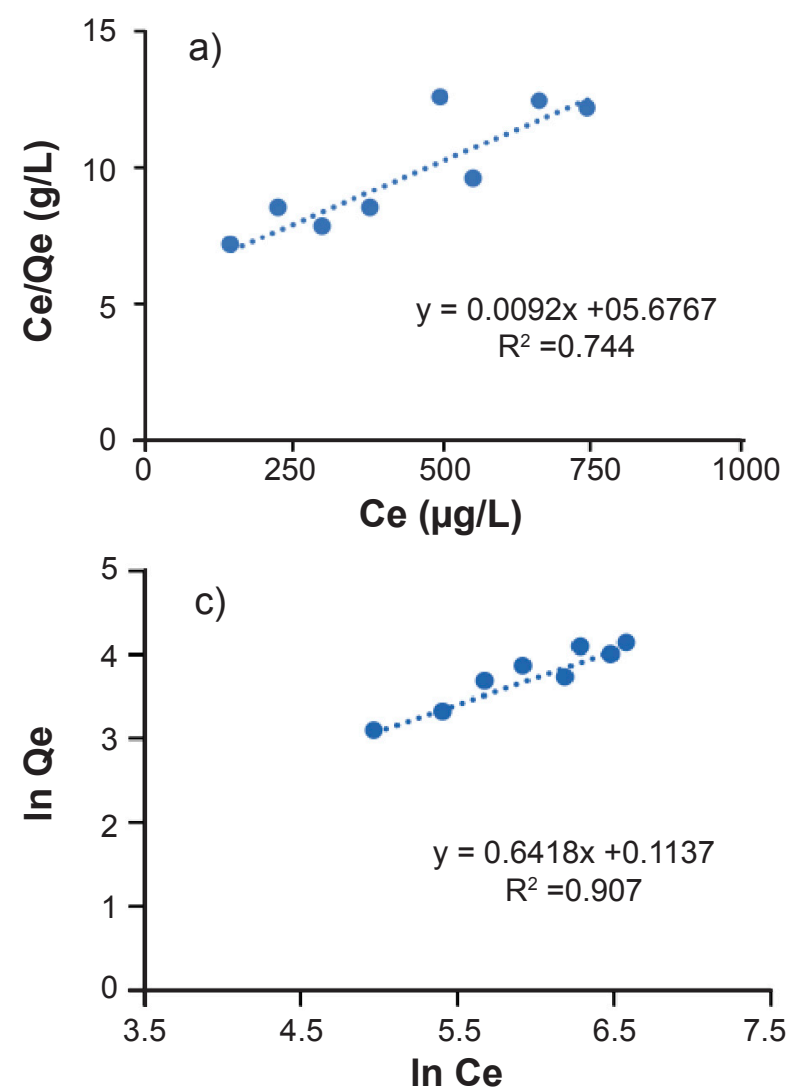

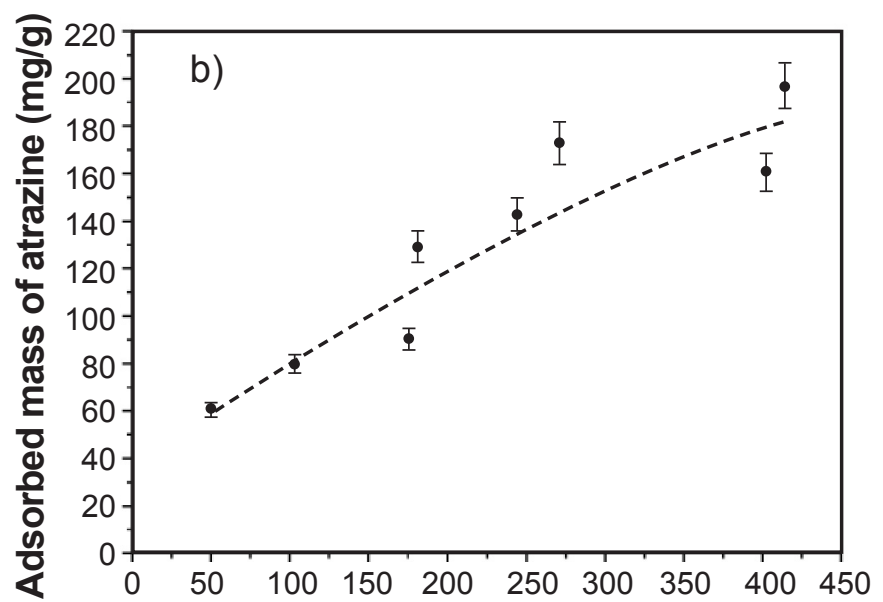

\section{Residual concentration of atrazine ( $\mu \mathrm{g} / \mathrm{L})$}
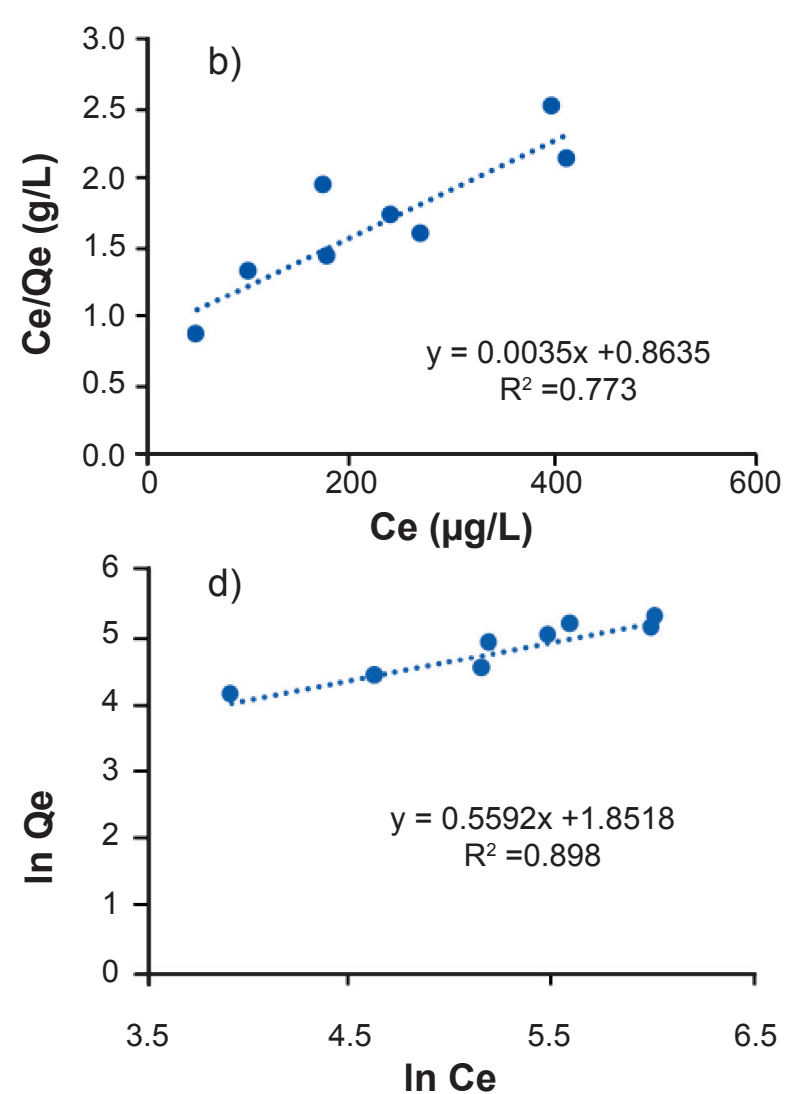

Figure 5: Linearization by Langmuir model (a,b) and Freundlich model (c,d) for the adsorption of atrazine by in natura clay (a,c) and A1 clay (b,d).

Table III - Parameters of isotherms in natura and organophilic A1 clays.

\begin{tabular}{cccccc}
\hline \multirow{2}{*}{ Clay } & \multicolumn{2}{c}{ Langmuir } & \multicolumn{3}{c}{ Freundlich } \\
& $\mathrm{b}$ & $\mathrm{R}^{2}$ & $\mathrm{~K}_{\mathrm{F}}$ & $1 / \mathrm{n}$ & $\mathrm{R}^{2}$ \\
\hline In natura & 108.7 & 0.74 & 0.892 & 0.6418 & 0.91 \\
$\mathrm{~A} 1$ & 285.7 & 0.77 & 6.379 & 0.5592 & 0.90 \\
\hline
\end{tabular}

\section{CONCLUSIONS}

Organophilic clays prepared from the in natura bentonite clay were investigated. It is concluded that the clays were obtained satisfactorily and the XRD analysis showed an increase in the basal distance $\left(\mathrm{d}_{001}\right)$ after the organophilization treatment, confirming the intercalation of quaternary ammonium salt molecules between the lamellae of the clays. The bands shown in the FTIR spectra were characteristic of quaternary ammonium salts and the TG analysis indicated the appearance of an additional mass loss stage, which was associated with the decomposition of organic molecules. Thus, changes in the clays, due to the exchange of inorganic cations for organic cations, led to interlamellar spaces 
available for the adsorption of organic contaminants, whose affinity for the clays was confirmed in the adsorption tests. In the study of isotherms for the adsorption of atrazine in aqueous solutions, a higher adsorption performance was achieved by A1 (cetyltrimethylammonium bromide) organophilic clay than the in natura clay, pointing to the potential use of this clay for the removal of the organic compounds.

\section{ACKNOWLEDGMENTS}

The authors gratefully thank CAPES for MS scholarship, for the laboratory of NCQP-UFES for FTIR, TG, and XRD analyses, and the laboratory of Natural Products (Prof. Dr. Warley S. Borges) for HPLC analysis.

\section{REFERENCES}

[1] A.R. Silva, V.H.C. Ferreira, Rev. Eletr. Mater. Proc. 3, 2 (2008) 26.

[2] J.F. Duarte-Neto, J.M. Cartaxo, G.A. Neves, R.R. Menezes, Rev. Eletr. Mater. Proc. 9, 1 (2014) 51.

[3] K.A. Hernández-Hernándeza, J. Illescasa, M.C. DíazNava, S. Martínez-Gallegosa, A.C. Muro-Urista, R.E. Ortega-Aguilara, E. Rodríguez-Alba, E. Rivera, Appl. Clay Sci. 157 (2018) 212.

[4] V. Iannuccelli, E. Maretti, A. Bellini, D. Malferrari, G. Ori, M. Montorsi, M. Bondi, E. Truzzi, Appl. Clay Sci. 158 (2018) 158.

[5] S. Pandey, J. Ramontja, Focus Sci. 2 , 4 (2016) 1.

[6] Anvisa, "Programa de análise de resíduos de agrotóxicos em alimentos", www.gov.br/anvisa/pt-br, ac. 22/11/2020.

[7] W.D.J. Callister, Ciência e engenharia de materiais: uma introdução, Livros Técn. Cient. Ed., Rio Janeiro (2002).

[8] L.B. de Paiva, A.R Morales, F.R.V. Díaz, Cerâmica 54, 330 (2008) 213.

[9] F.R. Valenzuela-Díaz, Eng. Mater. 189 (2001) 203.
[10] C. Bertagnolli, "Preparo e caracterização de argilas organofílicas para remoção de derivados do petróleo", M.Sc. Diss., Unicamp, Campinas (2010).

[11] E.R.C. Coelho, H. Vazzoler, W.P. Leal, Eng. Sanit. Ambient. 17, 4 (2012) 421.

[12] O.A.A. Santos, M.G.C. Silva, in VI Conf. Bras. Temas Tratam. Térm., Atibaia (2012).

[13] S. Yariv, Appl. Clay Sci. 24, 3 (2004) 225.

[14] P.S. Santos, Ciência e tecnologia de argilas, $2^{\mathrm{a}}$ ed., Edgard Blucher, S. Paulo (1989).

[15] A.A. Silva, F.R. Valenzuela-Diaz, G.S.V. Martins, M.G.F. Rodrigues, Cerâmica 53, 328 (2007) 417.

[16] F.R.V. Díaz, P.S. Santos, Quím. Nova 24, 3 (2001) 345.

[17] Z. Li, W.T. Jiang, H. Hong, Spectrochim. Acta A Mol. Biomol. Spectrosc. 71 (2008) 1525.

[18] W.A. Zhang, D.Z. Chen, H.Y. Xu, X.F. Shen, Y.E. Fang, Eur. Polym. J. 39 (2003) 2323.

[19] W.L.L. da Silva, J. de A. Simoni, Cerâmica 64, 371 (2018) 403.

[20] H.S. Ferreira, L.F.A. Campos, R.R. Menezes, J.M. Cartaxo, L.N.L. Santana, G.A. Neves, H.C. Ferreira, Cerâmica 59, 350 (2013) 277.

[21] E. Grundgeiger, Y.H. Lim, R.L. Frost, G.A. Ayoko, Y. Xi, Appl. Clay Sci. 105 (2015) 252.

[22] D.A. Carmo, A.P.B. Carmo, J.M.B. Pires, J.L.M. Oliveira, Rev. Amb. Água 8, 1 (2013) 133.

[23] C.C. Muller, M.T. Raya-Rodriguez, L.F. Cybis, Eng. Sanit. Ambient. 14, 1 (2009) 29.

[24] D.M. Ruthven, Principles of adsorption and adsorption processes, Un. New Brunswick, Fredericton (1984).

[25] C.C. Muller, “Adsorção em carvão ativado em pó para a remoção de microcistina de água de abastecimento público", M.Sc. Diss., UFRGS, Porto Alegre (2008).

[26] Z. Yu, S. Peldszus, P.M. Huck, Water Res. 42 (2008) 2873.

[27] N. Yilmaz, S. Yapar, Appl. Clay Sci. 27, 3 (2004) 223.

(Rec. 03/05/2020, Rev. 19/08/2020, 07/12/2020, Ac. $12 / 12 / 2020)$ 